\title{
Bronchiolitis and asthma: are they related?
}

Wheezing lower respiratory illnesses are important causes of morbidity in childhood. Much attention has been focused on the relation between wheezing illness in infancy and subsequent asthma. The study of risk factors for asthma is difficult because of the number of confounding influences contributing to its development, and the difficulty in defining the outcome entity which is a clinical syndrome that varies substantially in presentation and clinical course.

Asthma is a condition characterised by acute attacks of wheezing, shortness of breath, and cough which is, at least partially, reversible. Airway changes responsible for these symptoms are believed to be associated with airway hyperresponsiveness, atopy, and an inflammatory response leading to mucosal infiltration of inflammatory cells, oedema, mucus hypersecretion, and smooth muscle contraction.

\section{Genes and the environment}

The predisposition to asthma and atopy is inherited. Family and twin studies have shown that total IgE production has a heritability close to $80 \% .^{1}$ This may involve a single gene although the mode of inheritance has not yet been clearly defined. ${ }^{2}$ On the other hand, the production of specific IgE against allergens appears to be influenced more by environmental than genetic factors. ${ }^{3}$ Cookson et al have recently reported a linkage between $\mathrm{IgE}$ responses, underlying asthma and rhinitis, and a marker on the long arm of chromosome 11,4 and have suggested that this marker may be responsible for the receptor for high affinity IgE. ${ }^{5}$ However, others have not been able to confirm an association between this marker and atopy. ${ }^{6}$ Bronchial hyperresponsiveness measured in early life was found to be increased in infants with a family history of asthma. ${ }^{7}$ In this study levels of IgE in cord blood in these infants were unrelated to their levels of bronchial hyperresponsiveness. The relation between the genetics of asthma, atopy, and bronchial hyperresponsiveness remains unclear. The genetic susceptibility to lower respiratory symptoms is also expressed by gender. In the study by Horwood $e t a l^{8} 14.3 \%$ of the males had wheezed by six years of age compared with $6 \cdot 3 \%$ of the females. The reasons for this difference in prevalence are not well understood, but males do appear to have increased muscle tone, ${ }^{9}$ and an increased risk of airway hyperresponsiveness ${ }^{10}$ and positive IgE responses to allergens. ${ }^{11}$

Environmental factors that appear to be important for inducing or "switching on" asthma in the genetically predisposed host include irritants, allergens, and viral infections. It is presumed that these agents promote the inflammatory cascade characteristic of that which would lead to a clinical pattern of asthma.

Several studies have shown that children exposed to environmental tobacco smoke have an increased risk of asthma symptoms, ${ }^{1213}$ bronchial hyperresponsiveness, ${ }^{10}$ and abnormal lung function. ${ }^{7}$ The mechanism by which environmental tobacco smoke causes asthma symptoms is not well understood; it may lead to abnormal airway growth during pregnancy, ${ }^{714}$ non-specific increase in IgE levels, ${ }^{15}$ or increased sensitisation to aeroallergens. ${ }^{11}$ Environmental tobacco smoke may therefore affect lung growth and development leading to lower respiratory symptoms, it may trigger attacks of asthma, or it may increase the prevalence of asthma. There is little evidence to support the latter.
Exposure to allergens in early life may be important in the development of subsequent asthma and atopic disease. A high incidence of asthma has been found in children born in certain months of the year, although the pattern may change from year to year and differ from country to country. ${ }^{16}$ Although allergic responses to foods such as nuts and milk are frequently detected in early childhood, they appear to be transient and there have been no convincing studies to show that these influence the development of asthma. It is more likely that aeroallergens such as house dust mite, grass pollens, and cat dander may contribute. ${ }^{17}$ Sporik et al have reported higher levels of house dust mite allergen in the first year of life in the homes of those who subsequently develop asthma. ${ }^{18}$ Fungi may contribute in those countries with considerable dampness of houses during parts of the year.

\section{Respiratory infections}

The relation between viral infections and subsequent asthma is even more complex, and is becoming more contentious but possibly more interesting. Viral infections are the most important triggers of asthma attacks and it has long been considered that respiratory tract infections, particularly during early childhood, could contribute in a causal way to the development of airway hyperresponsiveness and asthma.

In normal adults viral respiratory illnesses cause airway obstruction, predominantly in the smaller airways, and airway hyperresponsiveness which persists for weeks beyond the clinical viral infection. ${ }^{19}$ Controversy arises as to whether this phenomenon can occur in all cases, or only in those atopic subjects with a predisposition to asthma, and whether it is transient or leads to persisting abnormalities of lung function. Samet et al have been unable to find conclusive evidence of persisting abnormality of lung function following viral infections in childhood. ${ }^{20}$ Martinez et $a l^{11}$ have noted that abnormal lung function is likely to be present from birth in those who subsequently develop wheezing respiratory illness in infancy. What is the relation, therefore, between wheezing respiratory illnesses, particularly bronchiolitis, in infancy and subsequent asthma?

More than one third of children will have a wheeze associated lower respiratory illness during the first year of life. As most wheezing lower respiratory illnesses in infancy are associated with viral infections, environmental factors play an important part. Lower socioeconomic status, increased number of siblings, and daycare all increase the risk for lower respiratory tract illness. ${ }^{22}$ Breast feeding is protective against wheezing lower respiratory tract illness early in life, particularly in those at higher risk because of poorer socioeconomic conditions. ${ }^{22}$

Parental, particularly maternal, cigarette smoking is associated with an increased risk of wheezing lower respiratory symptoms and hospitalisation in exposed infants. ${ }^{23} 24$ Studies suggest that this relation may be because of an effect on the developing lung by maternal smoking during pregnancy. ${ }^{714}$

Infants born preterm, and those with chronic lung disease associated with prematurity and with the treatment of neonatal respiratory distress, are more likely to develop wheezing lower respiratory illness, severe bronchiolitis, and require hospitalisation. ${ }^{25}{ }^{26}$ Male infants also develop more severe lower respiratory illness and wheezing. The 
reason for the gender difference is unknown, but may relate to differences in lung function between the sexes. ${ }^{27}$

Some studies have found that infants with wheezing, and those admitted to hospital with bronchiolitis, have an increased family history of atopy, ${ }^{2829}$ while others suggest that no strong relation exists between family atopy and bronchiolitis in infancy. ${ }^{30}$ Halonen et $a l^{31}$ have shown, in fact, that levels of IgE in cord blood are inversely related to the risk of wheezing during the first year of life. Many infants wheeze during the first year of life and less than half of these are likely to develop asthma. Wheezing in the remaining infants appears to be related to a pre-existing difference in airway size or damage sustained during lung growth.

\section{Bronchiolitis}

The relation between bronchiolitis and other wheezing lower respiratory illnesses remains unclear. To understand better the relation between bronchiolitis and subsequent asthma, it is necessary to restrict the term "bronchiolitis" to a specific clinical syndrome caused by respiratory syncytial virus infection. This illness is associated with the onset of cough and wheeze in infants under 12 months of age who display hyperinflation with wheeze and fine inspiratory crackles audible thoughout the lung fields on auscultation. ${ }^{32}$ The clinical severity may vary from mild respiratory distress managed at home to severe distress requiring hospitalisation and ventilation. To include all wheezing episodes associated with respiratory infections in children under two years of age, as is sometimes done in reported studies, will certainly lead to confusion as many of these infants are likely to be asthmatic with sufficient criteria for that diagnosis.

Primary infection with respiratory syncytial virus develops in most children during the first two years of life. In the majority of cases the first infection resolves without major lower respiratory symptoms within one to two weeks. Some will develop a wheezy lower respiratory illness and some the clinical syndrome defined as bronchiolitis, the proportion depending on the rigidity with which the criteria for diagnosis are used. Approximately $2.5 \%$ will be hospitalised and $5-25 \%$ of these will be admitted to the intensive care unit. This is more likely to occur in those with underlying abnormalities such as chronic lung disease of prematurity, cystic fibrosis, congenital heart disease, and immune deficiency syndromes. ${ }^{334}$

Bronchiolitis in developing countries should be considered independently as the clinical pattern and subsequent outcome are very likely to differ from those seen in developed countries. The reasons for the differences are not clear, but criteria that should be taken into account include intensity of viral infection, age of infection, pollution, and associated bacterial infections.

\section{Bronchiolitis and asthma}

Are infants who develop bronchiolitis on exposure to respiratory syncytial virus different from those who develop a non-specific wheezing lower respiratory illness and those who do not develop any lower respiratory symptoms? Are those who develop bronchiolitis manifesting their first attack of asthma? Are they infants who already have abnormally small airways responding, in the limited way they can, to inflammation and oedema of the airway wall? Does the respiratory syncytial viral infection cause non-specific airway damage or induce a specific inflammatory process that results in the development of asthma? The precise relation between bronchiolitis during infancy and the development of asthma remains controversial.

The proportion of infants who develop recurrent wheezing, airway hyperresponsiveness, asthma, or persisting abnormalities of lung function after bronchiolitis will depend on the criteria used for defining bronchiolitis. Some published studies are hospital based while others are community based; some restrict their cases to those with proven respiratory syncytial virus infection; some limit the age range to the first 12 months of life, while others extend this to two years. Most find that these infants subsequently experience more respiratory symptoms than those who have not had acute bronchiolitis, although the symptoms vary in severity and tend to diminish with time. A number of long term prospective studies of children admitted to hospital with bronchiolitis positive for respiratory syncytial virus have shown that approximately $75 \%$ will experience wheezing in the first two years after the initial illness, more than $50 \%$ will still wheeze three years later, and approximately $40 \%$ continue to wheeze after five years. ${ }^{2835-39}$ Rooney and Williams ${ }^{28}$ and Zweiman et $a l^{39}$ found that those most likely to have persistent wheezing were children born to parents with a history of atopic illnesses. However, Pullan and $\mathrm{Hey}^{30}$ and Murray et $a l^{37}$ found that atopy in the family was not a significant risk factor for wheezing after bronchiolitis. Murray et $a l^{37}$ did find that personal atopy was more prevalent in the symptomatic children after bronchiolitis.

Gurwitz et $a l^{38}$ and Murray et $a l^{37}$ found an increased incidence of bronchial hyperresponsiveness to histamine or methacholine after bronchiolitis $(76 \%$ and $57 \%$ respectively). They also found that few of the patients with bronchial hyperresponsiveness had troublesome symptoms and that bronchial hyperresponsiveness did not correlate with wheezing, many in the control groups who had not had bronchiolitis having wheezing and bronchial hyperresponsiveness. These findings confirm those of Pullan and Hey. ${ }^{30}$

McConnochie and Roghmann ${ }^{40}$ evaluated children 7-8 years after bronchiolitis who were managed in a community based paediatric practice. Upper respiratory allergy, bronchiolitis, and passive smoke exposure were significantly related to later wheezing, but their analysis suggested that bronchiolitis accounted for only $1 \%$ of the risk for subsequent wheezing.

\section{Immunopathology of bronchiolitis}

Welliver $e t a l^{41}$ collected nasal secretions from infants with documented infection with respiratory syncytial virus to determine whether IgE specific antibody to the virus could be found. Those with bronchiolitis and pneumonia who also wheezed had higher titres of respiratory syncytial virus specific IgE antibody in their nasal secretions than did subjects without airway obstruction. This group also had greater concentrations of histamine in their nasal secretions and lower arterial oxygen concentrations. They prospectively monitored 38 infants for two years after the initial episode of bronchiolitis ${ }^{42}$ and found that $70 \%$ of those with high IgE antibody titres experienced wheezing on later occasions compared with $20 \%$ of those with undetectable titres. Welliver and Duffy ${ }^{43}$ examined the same cohort at 7-8 years of age and found that recurrent wheeze following bronchiolitis was associated with an initial IgE response, although many of those with an IgE response had become asymptomatic. Recurrent wheezing was also strongly associated with a family history of atopy and positive skin tests. The respiratory syncytial virus specific IgE response was unrelated to abnormalities of 
pulmonary function and airway reactivity, but these measurements were related to atopy and passive cigarette smoke exposure. Serum IgE levels are not elevated after acute viral bronchiolitis, ${ }^{44}$ and there does not appear to be any predisposition of the infant with bronchiolitis to produce IgE.

Viral infections of the airways may be associated with direct epithelial injury, inflammation, sensitisation of cholinergic afferent fibres, diminished $\beta$ adrenergic function, production of virus specific antibodies, and changes in the mediator release process. These phenomena have been very well reviewed by Busse, ${ }^{45}$ Everard and Milner, ${ }^{46}$ and Morgan and Martinez. ${ }^{47}$

Tepper et $a l^{48}$ found increased responsiveness to inhaled methacholine in infants after bronchiolitis. The bronchiolitic infants maintained a greater airway responsiveness than a control group of the same age. Beta-adrenergic function in human white cells is compromised when incubated with respiratory viruses. ${ }^{45} \mathrm{~A}$ virus effect on catecholamine regulation of cell function could establish a permissive situation to promote the release of mast cell mediators and thus enhance airway inflammation, obstruction, and reactivity. Although a strong association exists between levels of virus specific IgE antibody and the development of airway obstruction during bronchiolitis and subsequent wheezing, evidence that this mechanism is important in the development of long term changes is not strong. ${ }^{43}$ Cytotoxic $\mathrm{T}$ cells appear to be important in recovery from respiratory syncytial virus infections, yet some have suggested that cytotoxic $T$ cells may contribute to the lung disease. Various changes in CD4/CD8 cell numbers are reported, but it is difficult to know to what extent changes in peripheral blood reflect changes within the lower respiratory tract. ${ }^{46}$ Impairment of $\mathrm{T}$ cell function may be important in the development of bronchiolitis, but further studies are necessary to define any altered immunoregulation. Neutrophils appear to be the dominant inflammatory cell in infants with acute respiratory syncytial virus bronchiolitis. ${ }^{46}$ Alterations in function of white blood cells with respiratory syncytial virus infection may play a part in the development of long term disease within the respiratory tract, but the contribution to asthma and chronic airflow limitation has not been defined.

\section{Conclusion}

A significant number of children wheeze in the first year of life, but only a minority develop acute viral bronchiolitis. Some, but not all, go on to develop asthma. The relation between these three syndromes is still confused. Acute viral bronchiolitis represents a clinical syndrome usually associated with infection with respiratory syncytial virus. It varies in its severity and manifestations in different societies. Whether bronchiolitis is the first respiratory illness in an infant prone to wheezing lower respiratory illness or an entity with a specific immunological mechanism remains to be determined. The remission in wheezing that occurs in many children with bronchiolitis and other wheezing lower respiratory illnesses suggests that the problem in these is probably related to smaller airways associated with male gender, maternal smoking, and preterm delivery. The improvement results from lung growth and development. Viral infections, including respiratory syncytial virus, are important triggers of acute attacks of asthma and increased airway responsiveness. Wheezing in some infants infected with respiratory syncytial virus, who have the appropriate genotype and who have been exposed to relevant allergen inducers, will be an early expression of asthma. It has not been definitely shown that infection with respiratory syncytial virus alone can induce asthma in those who are not otherwise predisposed..$^{49}$

Department of Paediatrics,

Princess Margaret Hospital for Children, The Children's Hospital Medical Centre, GPO Box D184,

Perth,
Western Australia 6001

1 Myers D, Marsh D. Report on a National Institute of Allergy and Infectious Diseases sponsored workshop on the genetics of total immuno-
globulin E levels in humans. $\mathcal{F}$ Allergy Clin Immunol 1981;67:167-70. globulin E levels in humans. F Allergy Clin Immunol 1981;67:167-70.
Gerrard J, Rao D, Morton N. A genetic study of immunoglobulin E. Am 2 Gerrard J, Rao D, Morton N. A genetic study of immunoglobulin E. Am $\mathcal{F}$

3 Wutrich B, Baumman E, Fries R, Schnyder UW. Total and specific IgE (RAST) in atopic twins. Clin Allergy 1981;11:147-54.

4 Cookson W, Sharp P, Faux JA, Hopkins JM. Linkage between immunoglobulin $\mathrm{E}$ responses underlying asthma and rhinitis and chromosome 11q. Lancet 1989;i:1292-5.

5 Sandford AJ, Shirakawa T, Moffatt MT, Daniels SE, Ra C, Faux JA, et al. Localisation of atopy and $\beta$-subunit of high affinity $\mathrm{IgE}$ receptor $\left(\mathrm{Fe} \varepsilon \mathrm{R}_{1}\right)$ on chromosome 11q. Lancet 1993;341:332-4.

6 Morton NE. Major loci for atopy? Clin Exp Allergy 1992;22:1041-3.

7 Young S, LeSouëf PN, Geelhoed G, Stick SM, Turner KJ, Landau LI The influence of a family history of asthma and parental smoking on the level of airway responsiveness in infants soon after birth. $N \mathrm{Engl} F \mathrm{Med}$ 1991;324:1168-73.

8 Horwood LJ, Fergusson DM, Shannon FT. Social and familial factors in the development of early childhood asthma. Pediatrics 1988;75:859-68.

9 Landau LI, Morgan W, McCoy KS, Taussig LM. Gender related differences in airway tone in children. Pediatr Pulmonol 1993;16:31-5.

10 Martinez F, Antognoni G, Macri F, Bonci E, Midulla F, DeCastro G, et al. Parental smoking enhances bronchial responsiveness in nine year old children. Am Rev Respir Dis 1988;138:518-23.

11 Ronchetti R, Bonci E, Cutrera R, DeCastro G, Indinnimeo L, Midulla F, et al. Enhanced allergic sensitization related to parental smoking. Arch Dis Child 1992;67:496-500.

12 Gortmacher SL, Walker DK, Jacobs RN, Ruch-Ross H. Parental smoking and the risk of asthma. Am 7 Public Health 1982;72:574-9.

13 Weiss ST, Tager IB, Schenker M, Speizer FE. The health effects of involuntary smoking. Am Rev Respir Dis 1983;128:933-42.

14 Hanrahan JP, Jager IB, Segal MR, Tosteson TD, Castile RG, Van Vunakis $\mathrm{H}$, et al. The effect of maternal smoking during pregnancy on early lung function. Am Rev Respir Dis 1992;145:1129-35.

15 Ronchetti R, Macri F, Ciofetta E, Indinnimeo L, Cutrera R, Bonci E, et al. Increased serum immunoglobulin $\mathrm{E}$ and increased prevalence of eosinophilia in nine year old children of smoking parents. $\mathcal{f}$ Allergy Clin Immunol 1990;86:400-7.

16 Haberg N. Birth season variation in asthma and allergic rhinitis. Clin Exp Allergy 1989;19:643-8.

17 Sears M, Herbison G, Holdaway M, Hewitt CJ, Flannery EM, Silva PA. The relative risk of sensitivity to grass pollen, house dust mite and cat dander in the development of childhood asthma. Clin Exp Allergy dander in the

18 Sporik R, Holgate ST, Platts-Mills TAE, Cogswell JJ. Exposure to house dust mite allergen (Der $p$ ) and the development of asthma in childhood. $N$ Engl F Med 1990;323:502-7.

19 Hall WJ, Hall CB, Speers DM. Respiratory syncytial virus infection infection in adults: virologic and serial pulmonary function studies. Ann Intern Med 1978;88:203-5.

20 Samet JM, Tager IB, Speizer FE. The relationship between respiratory illness in childhood and chronic airflow obstruction in adulthood. Am Rev Respir Dis 1983;127:508-23.

21 Martinez FD, Morgan WJ, Wright AL, Holberg CJ, Taussig LM. Diminished lung function as a predisposing factor for wheezing respiratory illness in infants. $N$ Engl f Med 1988;319:1112-7.

22 Wright A, Holberg C, Martinez F, Morgan WJ, Taussig LM. Breast feeding and lower respiratory tract illness in the first year of life. $B M \mathcal{J}$ 1989;299:946-9.

23 Harlap S, Davies A. Infant admissions to hospital and maternal smoking. Lancet 1974;i:529-32.

24 Ware JH, Dockery D, Spiro A, Speizer FE, Ferris BG. Passive smoking, gas cooking and respiratory health of children living in six cities. Am Rev Respir Dis 1984;129:366-74.

25 Greenough A, Maconochie I, Yuksel B. Recurrent respiratory symptoms in the first year following preterm delivery. $\mathcal{F}$ Perinat Med 1990;18:489-94.

26 Groothius J, Gutierrez K, Lauer BA. Respiratory syncytial virus infection in children with bronchopulmonary displasia. Pediatrics 1988;82:199203.

27 Tepper R, Morgan W, Cota K, Wright A, Taussig LM. Physiologic growth and development of the lung during the first year. Ann Rev Respir Dis 1986;134:513-9.

28 Rooney JC, Williams HE. The relationship between proved viral bronchiolitis and subsequent wheezing. $\mathcal{F}$ Pediatr 1971;79:744-77.

29 Mok JYQ, Simpson H. Symptoms, atopy and bronchial reactivity after lower respiratory infection in infancy. Arch Dis Child 1984;59:299-305.
low

30 Pullan C, Hey E. Wheezing, asthma and pulmonary dysfunction 10 years after infections with respiratory syncytial virus in infancy. $B M \mathcal{J}$ 1982;284:1665-9.

31 Halonen M, Stein D, Taussig LM, Wright A, Ray CG, Martinez FD. The predictive relationship between serum IgE levels at birth and subsequent incidences of lower respiratory illnesses and eczema in infants. Am Rev Respir Dis 1992;146:866-70.

32 Phelan PD, Landau LI, Olinsky A. Respiratory illness in children. Oxford: Blackwell, 1982:76-8.

33 Hall CB, Walsh EE, Schnabel KC, Long CE, McConnochie KM, Hildreth $\mathrm{SW}$, et al. Occurrence of group A and $\mathrm{B}$ of respiratory syncytial virus over 15 years: associated epidemiologic and clinical characteristics in hospitalized and ambulatory children. F Infect Dis 1990;162:1283-90. 
34 Carmack MA, Prober CG. Severe respiratory syncytial virus disease in children. Curr Opin Pediatr 1992;4:457-61.

35 Henry RL, Hodges IGC, Milner AD, Stokes GM. Respiratory problems two years after acute bronchiolitis in infancy. Arch Dis Child 1983;58:713-6.

36 Webb MSC, Henry RL, Milner AD, Stokes GM, Swarbrick AS. Continuing respiratory problems three and a half years after acute viral bronchioling respiratory problems three and a

37 Murray M, Webb MSC, O'Callaghan C. Respiratory status and allergy after bronchiolitis. Arch Dis Child 1992;67:482-7.

38 Gurwitz D, Mindorrf C, Levison H. Increased incidence of bronchial reactivity in children with a history of bronchiolitis. $f$ Pediatr 1981;98:551-5

39 Zweiman B, Schoenwetter WF, Pappano JE, Tempest B, Hildreth EA Patterns of allergic respiratory disease in children with a past history of bronchiolitis. F Allergy Clin Immunol 1971;48:283-9.

40 McConnochie $\mathrm{K}$, Roghmann $\mathrm{K}$. Bronchiolitis as a possible cause of wheezing in childhood: new evidence. Pediatrics 1984;74:1-10.

41 Welliver RC, Wong DT, Sun M, Middleton E Jr, Vaughan RS, Ogra PL. The development of respiratory syncytial virus specific IgE and the release of histamine in nasopharyngeal secretions after infection. $N$ Engl $\mathscr{f}$ Med 1981;305:842-7.
42 Welliver RC, Sun M, Rinaldo D, Ogra PL. Predictive value of respiratory syncytial virus specific IgE responses for recurrent wheezing following bronchiolitis. F Pediatr 1986;109:776-80.

43 Welliver RC, Duffy L. The relationship of RSV specific immunoglobulin IgE antibody responses in infancy, recurrent wheezing and pulmonary function at 7-8 years. Pediatr Pulmonol 1993;15:19-27.

44 Polmar SH, Robinson LD, Minnefor AB. Immunoglobulin E in bronchiolitis. Pediatrics 1972;50:274-84.

45 Busse WW. Respiratory infections. Their role in airway responsiveness and the pathogenesis of asthma. F Allergy Clin Immunol 1990;85:671-83.

46 Everard ML, Milner AP. The respiratory syncytial virus and its role in acute bronchiolitis. Eur f Pediatr 1992;151:638-51.

47 Morgan WJ, Martinez FD. Risk factors for developing wheezing and asthma in childhood. Pediatr Clin North Am 1992;39:1185-203.

48 Tepper RS, Rosenberg D, Eigen H. Airway responsiveness in infant following bronchiolitis. Pediutr Pulmonol 1992;13:6-10.

49 Wilson NM. Wheezy bronchiolitis revisited. Arch Dis Child 1989;64 1194-9.

50 Samet JM, Tager IB, Spiezer FE. The relationship between respiratory illness in childhood and chronic airflow obstruction in adulthood. $A m R e v$ Respir Dis 1983;127:508-23. 